\title{
PROCESY KONTROLI KIEROWNICZEJ W POLSKICH PRZEDSIĘBIORSTWACH
}

\begin{abstract}
Z a r y s t r e ś c i: Poszukując sposobów zapewnienia wzrostu efektywności organizacje zmuszone są do podejmowania działań nakierowanych na ciągłe doskonalenie, których skuteczność uzależniona jest w dużej mierze od procesów kontroli działań, w tym przede wszystkim od kontroli kierowniczej. W opracowaniu, włączając się w dyskusję nad systemami kontroli, przedstawiono wyniki postępowania badawczego dotyczącego kształtu i efektywności procesów kontroli kierowniczej w polskich przedsiębiorstwach. Punktem wyjścia uczyniono zarysowanie istoty i natury kontroli kierowniczej oraz zdefiniowanie układu procesu kontroli kierowniczej, co w dalszej części stało się podstawą do przedstawienia wyników badań nad procesami kontroli kierowniczej w polskich przedsiębiorstwach.
\end{abstract}

S ł o w a k l u c z o w e: proces kontroli kierowniczej.

K l a s y fik a c j J E L: L21.

\section{ISTOTA I NATURA KONTROLI KIEROWNICZEJ}

Przeprowadzona analiza literatury przedmiotu [Bieniok 2004; Czermiński i in. 2001; Kieżun 1997; Mockler 1984; Przybyła 2001; Schermerhorn 2008] pozwala na przyjęcie, iż kontrola jest procesem mierzenia efektywności,

* Adres do korespondencji: Szymon Cyfert, Uniwersytet Ekonomiczny w Poznaniu, Wydział Zarządzania, Katedra Teorii Organizacji i Zarządzania, al. Niepodległości 10, 61-875 Poznań, e-mail: s.cyfert@ue.poznan.pl; Alina Skorb-Gała, Uniwersytet Ekonomiczny w Poznaniu, Wydział Zarządzania, Katedra Teorii Organizacji i Zarządzania, al. Niepodległości 10, 61-875 Poznań. 
którego istotą jest porównywanie rzeczywistych rezultatów z tym, co zostało zaplanowane, wykrycie i ocena powstałych odchyleń, formułowanie oraz wdrażanie zaleceń korygujących, dzięki którym rzeczywiste działania $\mathrm{w}$ przedsiębiorstwie są zgodne $\mathrm{z}$ zaplanowanymi celami. W literaturze wskazuje się, iż kontrola jest istotnym czynnikiem warunkującym powodzenie działań realizowanych w organizacjach, ponieważ poprzez wykorzystanie systemu kontroli menedżerowie mogą dopasować umiejętności, zadania i wyniki pracowników do celów i aspiracji organizacji [Cyert i March 1992].

Kontrola kierownicza jest szczególnym rodzajem kontroli, która sprawowana jest przez zwierzchników nad podwładnymi w celu sprawdzenia prawidłowości wykonywanych przez nich zadań [Schmid 2000]. W literaturze przedmiotu kontrolę kierowniczą definiuje się jako systematyczne działania kadry kierowniczej realizowane w formie procesu [Przybyła 2001; Kuc 2002], jednocześnie wskazując, że za skuteczność realizacji szeroko rozumianej kontroli w przedsiębiorstwie w największym stopniu odpowiadają kierownicy różnych szczebli zarządzania [Schmid 2000].

W opracowaniu, bazując na krytycznej analizie literatury przedmiotu, przyjęto, iż kontrola kierownicza stanowi zorganizowany proces działania kadry kierowniczej polegający na porównywaniu rzeczywistych rezultatów z tym, co zostało zaplanowane, ocenę powstałych odchyleń, formułowanie oraz wdrażanie zaleceń korygujących, dzięki którym kierownicy doprowadzają do stanu, w którym działania rzeczywiste w przedsiębiorstwie są zgodne z zaplanowanymi celami [Skorb-Gała 2015]. W kontroli kierowniczej kierownicy sami wykonują czynności regulacyjne i sprawdzające oraz inicjują, względnie realizują czynności korygujące na powierzonym im odcinku działalności przedsiębiorstwa. Poprzez kontrolę kierowniczą kierownicy utrzymują aktywny kontakt z podwładnymi, interpretują sprawozdania i raporty o wynikach, a następnie wykorzystują te informacje do planowania konstruktywnych działań i zmian w przedsiębiorstwie.

\section{MODEL PROCESU KONTROLI KIEROWNICZEJ}

Działania realizowane przez kierowników w obszarze kontroli kierowniczej nie mogą być traktowane w kategoriach jednorazowego przedsięwzięcia, o charakterze pasywnym, stanowiącego wyłącznie reakcję organizacji na zmiany w otoczeniu. Brak ciągłości działań w kontroli kierowniczej ze względu na niemożność bieżącego reagowania na pojawiające się dysfunk- 
cje, a także ze względu na brak mechanizmu sprzężenia zwrotnego doprowadzi do obniżenia efektywności funkcjonowania organizacji.

Krytyczna analiza podejść do definiowania procesu kontroli kierowniczej przedstawionych w literaturze przedmiotu pozwala na wyróżnienie od czterech do dziesięciu etapów [Krzakiewicz, Cyfert 2013; Bieniok 2004]. Bazując na istniejących propozycjach, w opracowaniu przyjęto, iż w skład procesu kontroli kierowniczej stanowiącego zorganizowany proces działania kadry kierowniczej polegający na ocenie i analizie rzeczywistych wyników osiągniętych przez podległych pracowników z ustalonymi standardami, ocenę powstałych odchyleń oraz formułowanie i wdrożenie działań korygujących, wchodzi jedenaście działań realizowanych w układzie sekwencyjnym (zob. Schemat 1). Jednocześnie założono, iż działania składające się na proces kontroli kierowniczej należy sklasyfikować jako subproces znajdujący się na trzecim poziomie architektury procesów [Cyfert 2007]. 


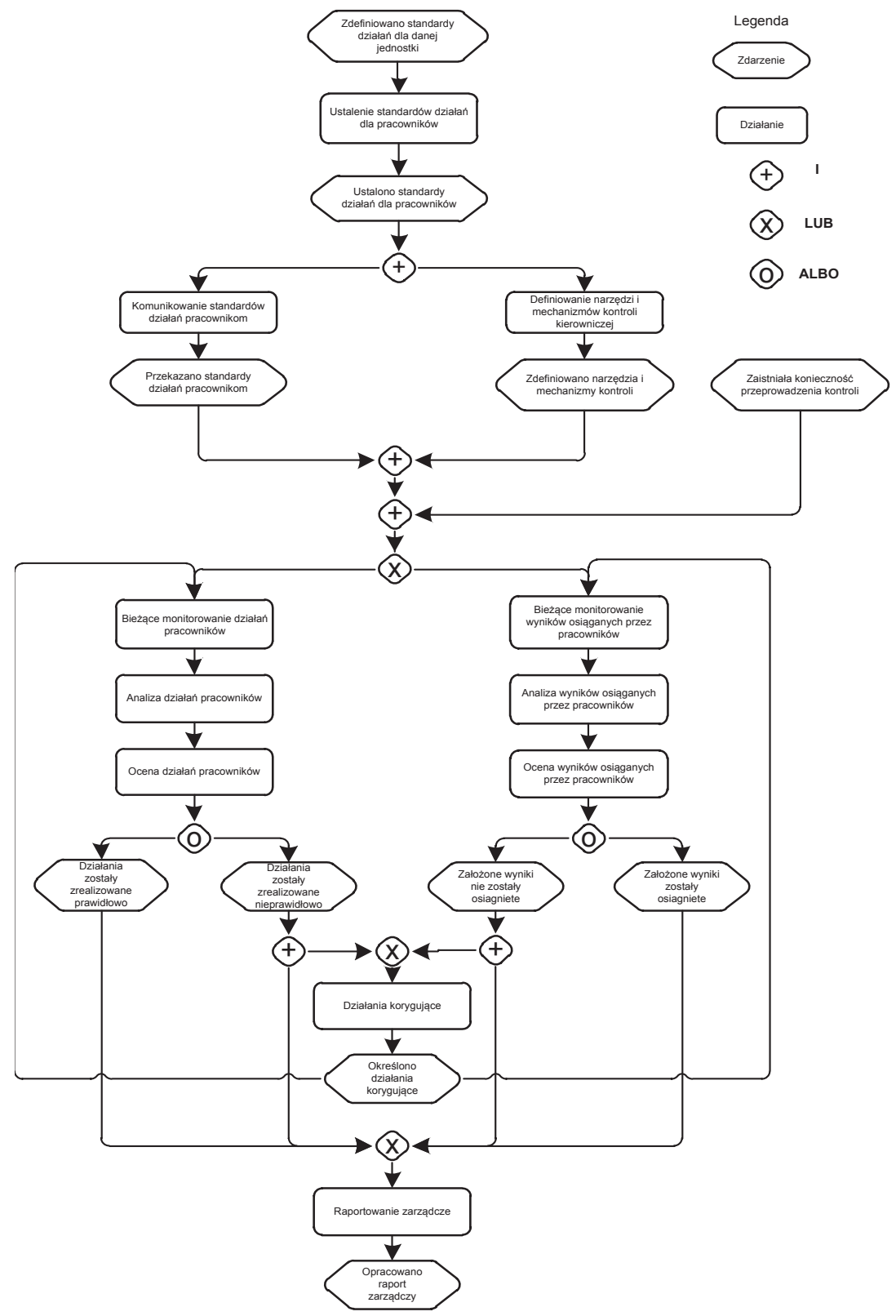

Schemat 1. Model procesu kontroli kierowniczej

Źródło: opracowanie własne. 


\section{METODYKA POSTEPOWANIA BADAWCZEGO I CHARAKTERYSTYKA PRÓBY BADAWCZEJ}

W postępowaniu badawczym zastosowano dwuetapową procedurę. Działania podjęte na pierwszym etapie (badanie pilotażowe) miały na celu zweryfikowanie poprawności konstrukcji kwestionariusza ankietowego. W rezultacie przeprowadzenia badań pilotażowych przeformułowano dwa pytania w kwestionariuszu ankietowym, a także wprowadzono siedem dodatkowych zmiennych w celu uszczegółowienia obszarów badawczych. Opracowany w ten sposób kwestionariusz ankietowy skierowany został, przy zastosowaniu poczty tradycyjnej oraz poczty elektronicznej, do kierowników $\mathrm{z}$ różnych szczebli zarządzania przedsiębiorstw wylosowanych z bazy GUS.

Wypełnione kwestionariusze otrzymano od 101 osób, z czego po weryfikacji, ze względu na niespójność danych, pozostawiono 92 kwestionariusze, przy czym $47,3 \%$ respondentów zatrudnionych było w przedsiębiorstwach dużych, $17,2 \% \mathrm{w}$ przedsiębiorstw średniej wielkości, $25,8 \% \mathrm{w}$ przedsiębiorstwach małych, zaś $9,7 \% \mathrm{w}$ przedsiębiorstwach mikro.

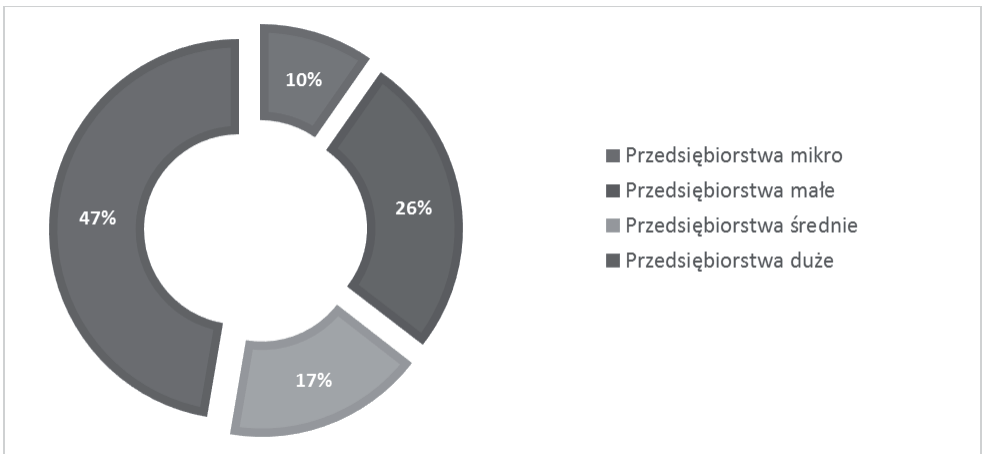

Wykres 1. Struktura badanych przedsiębiorstw ze względu na kryterium wielkości, $\mathrm{n}=92$

Źródło: opracowanie własne na podstawie przeprowadzonego postępowania badawczego. 
W strukturze badanych przedsiębiorstw, z punktu widzenia zaangażowanego kapitału (zob. Błąd! Nie można odnaleźć źródła odwołania.) dominują przedsiębiorstwa $\mathrm{z}$ kapitałem polskim (stanowiące ponad 59,1\% badanej populacji). Nieco mniejszy udział mają przedsiębiorstwa z kapitałem zagranicznym $(40,9 \%)$.

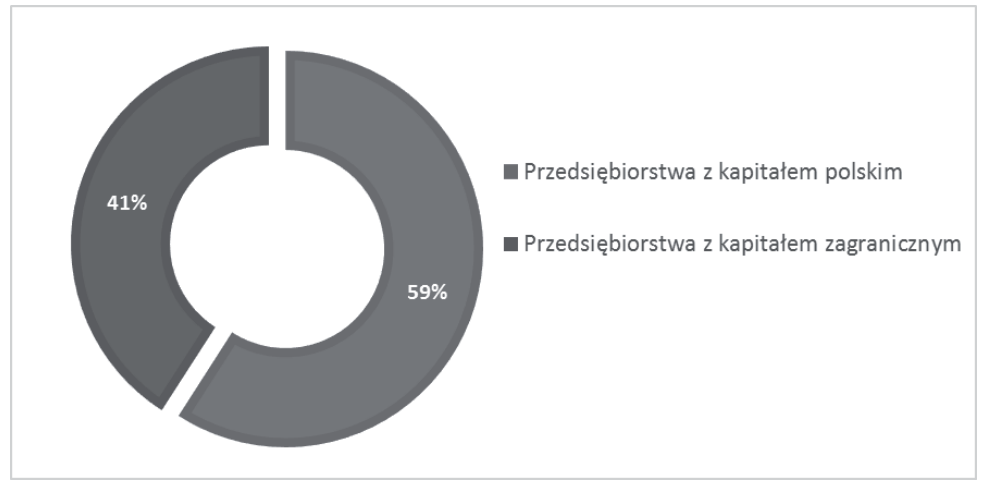

Wykres 2. Struktura badanych podmiotów ze względu na kryterium zaangażowanego kapitału, $\mathrm{n}=92$

Źródło: opracowanie własne na podstawie przeprowadzonego postępowania badawczego.

$\mathrm{W}$ badanej próbie największą grupę, z punktu kryterium dominującej działalności Sektora Gospodarki Narodowej (PKD), stanowiły osoby zatrudnione $\mathrm{w}$ przedsiębiorstwach usługowych $(13,3 \%)$, w przedsiębiorstwach przetwórstwa spożywczego $(8,3 \%)$ oraz w podmiotach prowadzących działalności finansową i ubezpieczeniową (6,7\%). Kolejne miejsce pod względem liczebności zajęły odpowiednio przedsiębiorstwa $\mathrm{z}$ branży chemicznej, przemysłowej oraz media.

Wśród osób wypełniających kwestionariusz ankiety dominującą grupę stanowiły osoby z najwyższego szczebla hierarchii organizacyjnej - 48\%. Kolejna grupę stanowili kierownicy średniego szczebla - 39,5\%, natomiast najmniej liczną grupę stanowili kierownicy z najniższego szczebla organizacyjnego, których udział w próbie wynosił 12,5\%. 


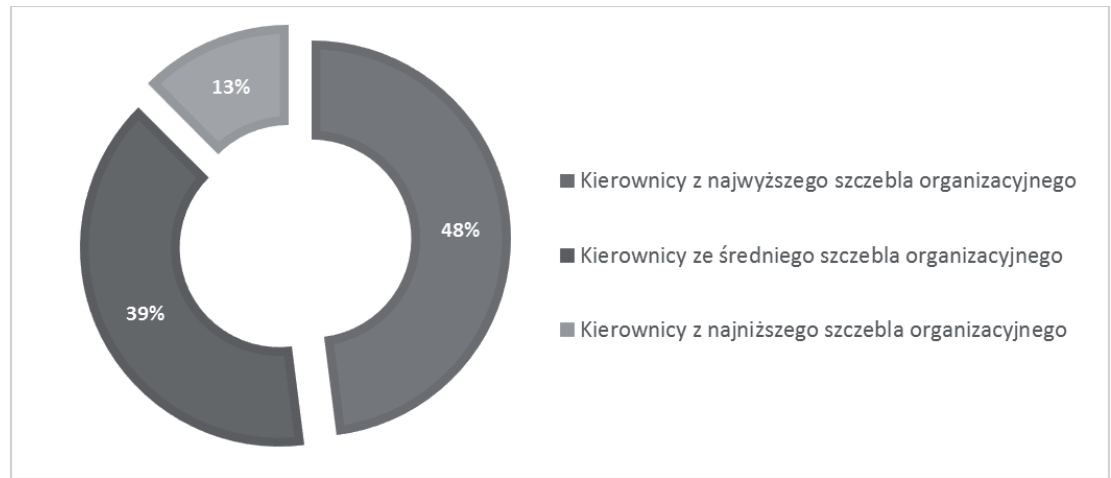

Wykres 3. Struktura badanych podmiotów ze względu na kryterium zajmowanego przez respondenta miejsca $w$ hierarchii organizacyjnej, $n=92$

Źródło: opracowanie własne na podstawie przeprowadzonego postępowania badawczego.

\section{WYNIKI PODSTĘPOWANIA BADAWCZEGO NAD PROCESAMI KONTROLI KIEROWNICZEJ W POLSKICH PRZEDSIĘBIORSTWACH}

Przeprowadzone postępowanie badawcze wykazało, że średni poziom realizacji działań w procesach kontroli kierowniczej kształtuje się na poziomie 0,61 maksymalnego poziomu realizacji działań, co pozwala ocenić ogólną intensywność działań w procesach kontroli kierowniczej jako powyżej przeciętne. Najwyższym poziomem intensywności charakteryzują się przedsięwzięcia realizowane w ramach etapów: Ocena wyników osiąganych przez pracowników $(0,71$ maksymalnego poziomu realizacji działań) oraz Ocena działań pracowników ( 0,70 maksymalnego poziomu realizacji działań), podczas gdy najniższą intensywność zaobserwować można w odniesieniu do działań realizowanych na etapach: Definiowanie narzędzi i mechanizmów kontroli kierowniczej ( 0,51 maksymalnego poziomu realizacji działań) oraz Raportowanie zarządcze ( 0,53 maksymalnego poziomu realizacji działań).

Dokonując interpretacji i oceny uzyskanych w postępowaniu badawczym wyników należy zwrócić uwagę na silne dowartościowanie działań ocennych, co wskazuje na aktywną rolę kierowników w procesach kontroli. $\mathrm{Z}$ drugiej jednak strony, pomimo relatywnie wyso- 
kiego poziomu intensywności realizacji działań ocennych, negatywnie należy ocenić niską wagę przywiązywaną przez kierowników do generowania raportów i doskonalenia narzędzi kontroli. Stan taki możne bowiem znaleźć przełożenie na sytuację, w której, pomimo dysponowania informacjami dotyczących dysfunkcji pojawiających się w procesie zarządzania, kierownik nie będzie w stanie wdrożyć odpowiednich zmian, względnie może doprowadzić do sytuacji, w której brak raportowania uniemożliwi podjęcie szybkiej interwencji ze strony przełożonego kierownika.

W kontekście wyników postępowania badawczego należy zwrócić uwagę na jeszcze jedno niekorzystne zjawisko. Wyniki postępowania badawczego pozwalają na wyprowadzenie spostrzeżenia, iż przeciętnie w $8 \%$ badanych podmiotów nie są realizowane działania kontrolne. Sytuacja ta nie byłaby niepokojąca, gdyby analizowane działania nie były rozpatrywane w kategoriach procesu, w którym następstwo i sekwencyjność działań jest niezwykle istotna. Przyjęcie założenia o następstwie i sekwencyjności działań oznacza bowiem, iż proces nie jest realizowany przynajmniej w 19\% badanych podmiotów - na taką wartość wskazano bowiem w odniesieniu do etapu Raportowanie zarządcze.

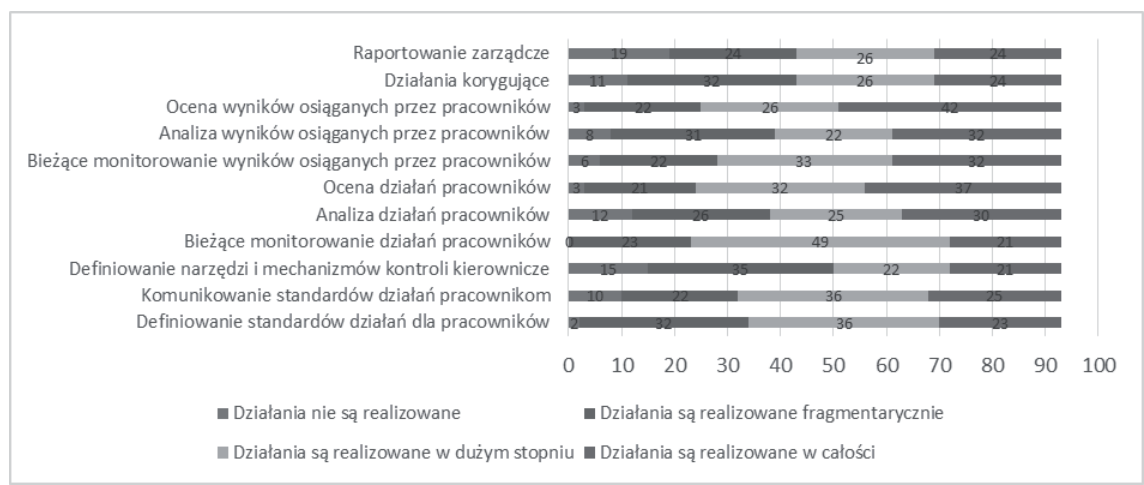

Wykres 4. Poziom intensywności działań w poszczególnych etapach procesu kontroli kierowniczej, $\mathrm{n}=92$

Źródło: opracowanie własne na podstawie przeprowadzonego postępowania badawczego.

Zdaniem respondentów najsilniejszy wpływ na poziom zorganizowania procesu kontroli kierowniczej mają działania realizowane na etapach: Ocena działań pracowników (wartość 3,54 w skali od 0 do 5) oraz Ocena 
wyników osiąganych przez pracowników (wartość 3,57 w skali od 0 do 5), zaś najsłabszy wpływ działania realizowane w obszarze Raportowanie zarządcze (wartość 2,65 w skali od 0 do 5) oraz Definiowanie narzędzi i mechanizmów kontroli kierowniczej (wartość 2,91 w skali od 0 do 5). Uzyskane wyniki są zbieżne z wynikami dotyczącymi poziomu intensywności działań w poszczególnych etapach procesu kontroli kierowniczej, co wskazuje na poprawność przeprowadzonego procesu badawczego. Można zatem przypuszczać, że poziom intensywności działań w poszczególnych etapach procesu kontroli kierowniczej jest konsekwencją postrzeganej siły wpływu danego etapu - niska wycena siły wpływu danego etapu skłaniała respondentów do zmniejszenia intensywności natężenia działań. Oznacza to, że dążenie do zwiększenia intensywności działań wymaga zmiany nastawienia kierowników odnośnie znaczenia poszczególnych etapów kontroli kierowniczej.

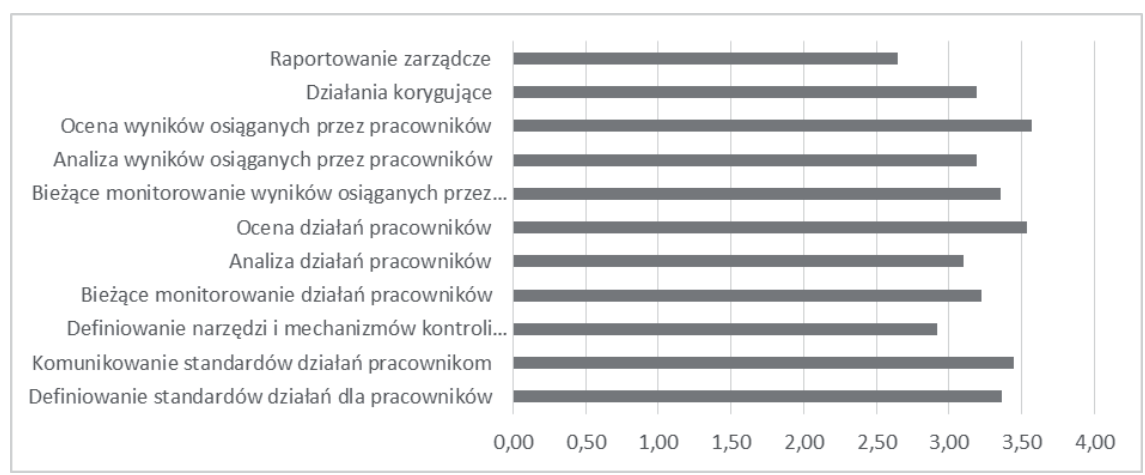

Wykres 5. Siła wpływu poszczególnych etapów procesu kontroli kierowniczej na poziom zorganizowania tegoż procesu, $\mathrm{n}=92$

Źródło: opracowanie własne na podstawie przeprowadzonego postępowania badawczego.

W przeprowadzonym postępowaniu badawczym przeanalizowano wpływ jedenastu potencjalnych barier procesu kontroli kierowniczej, zidentyfikowanych na podstawie analizy literatury przedmiotu. Zaliczono do nich: (1) brak systemu celów w przedsiębiorstwie, (2) niezrozumiałe standardy działań, (3) brak komunikacji w zakresie standardów działań, (4) niedostosowane metody i instrumenty kontroli kierowniczej, (5) brak nowoczesnych narzędzi informatycznych wspierających proces kontroli kierowniczej, (6) brak wyznaczonych krytycznych punktów kontroli kie- 
rowniczej, (7) nadmierna formalizacja procesu, (8) brak wyspecjalizowanych stanowisk i komórek ds. kontroli, (9) brak informacji o odchyleniach od planu, (10) brak działań korygujących oraz (11) brak raportowania zarządczego.

Analizując otrzymane wyniki postępowania badawczego należy zauważyć, że zidentyfikowane bariery mają przeciętny wpływ na skuteczność procesu kontroli kierowniczej $(2,41 \mathrm{w}$ skali od 0 do 5 , gdzie 0 oznacza brak wpływu, zaś 5 krytyczny wpływ danego czynnika na poziom skuteczności procesu kontroli kierowniczej). Wyniki postępowania pozwalają także na sformułowanie konkluzji, że dwie pierwsze bariery mające największy wpływ na skuteczność realizacji procesu kontroli kierowniczej - Brak nowoczesnych narzędzi informatycznych wspierających proces kontroli (wartość 2,86 w skali od 0 do 5) a także Niedostosowanie metod i instrumentów kontroli do realiów przedsiębiorstwa (średnia 2,62 w skali od 0 do 5) posiadają wspólny mianownik. Wysoki poziom ich negatywnego wpływu na przebieg kontroli kierowniczej jest naturalną konsekwencją niskiej intensywności działań realizowanych na etapie Definiowania narzędzi i mechanizmów kontroli, co pomimo deprecjacji znaczenia tego etapu, wskazuje na jego istotność. Kolejną krytyczną barierą jest brak komunikacji w zakresie standardów działań (średnia 2,57). Najsłabszy wpływ na procesy kontroli kierowniczej mają działania związane z Nadmierną formalizacją procesu kontroli $(2,19)$ oraz Brakiem wyznaczonych punktów kontroli $(2,23)$.

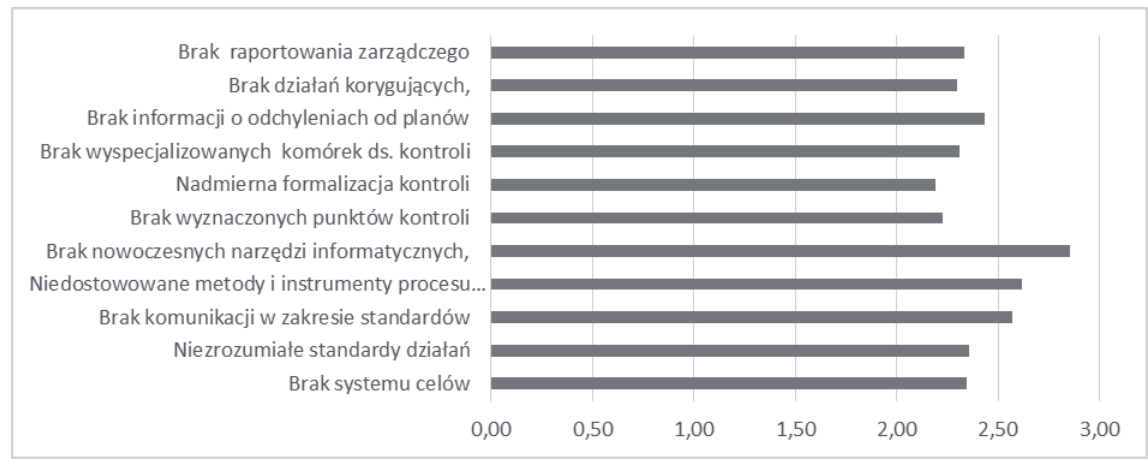

Wykres 5. Siła wpływu bariery w procesie kontroli kierowniczej, $\mathrm{n}=92$

Źródło: Opracowanie własne na podstawie przeprowadzonego postępowania badawczego. 


\section{PODSUMOWANIE}

Przeprowadzone postępowanie badawcze nad procesami kontroli kierowniczej w polskich przedsiębiorstwach pozwala na wyprowadzenie trzech generalnych konkluzji. Po pierwsze, na poziom realizacji działań w procesach kontroli kierowniczej, który oszacowany został jako przeciętny, największy wpływ mają działania związane z Oceną wyników osiąganych przez pracowników oraz Oceną działań pracowników. Po drugie, postępowanie badawcze wykazało, że poziom intensywności działań w poszczególnych etapach procesu kontroli kierowniczej, jest konsekwencją postrzeganej siły wpływu danego etapu, co oznacza, że dążenie do zwiększenia intensywności działań na poszczególnych etapach procesu kontroli kierowniczej wymaga zmiany nastawienia kierowników. Po trzecie, istotność barier mających największy wpływ na skuteczność procesu kontroli kierowniczej (Brak nowoczesnych narzędzi informatycznych wspierających proces kontroli oraz Niedostosowanie metod i instrumentów kontroli do realiów przedsiębiorstwa) jest konsekwencją niskiej intensywności działań realizowanych na etapie Definiowania narzędzi i mechanizmów kontroli, co wskazuje na zasadność doskonalenia tego działania.

\section{LITERATURA}

Bieniok H., Metody sprawnego zarządzania, Placet, Warszawa 2004.

Cyert R., March, J.G., A Behavioral Theory of the Firm (2 ed.), Wiley-Blackwell 1992.

Cyfert S., Strategiczne doskonalenie architektury procesów w zarządzaniu przedsiębiorstwem, Wyd. AE w Poznaniu, Poznań 2007.

Czermiński A., Czerska M., Nogalski B., Rutka R., Apanowicz J., Zarządzanie organizacjami, Dom Organizatora, Torun 2001.

Kieżun W., Sprawne zarzadzanie organizacją. Zarys teorii i praktyki, AGH, Warszawa 1997.

Krzakiewicz, Cyfert S., Teoretyczne problemy zarzadzania organizacjami, Wyd. UE w Poznaniu, Poznań 2013.

Kontrola i kontroling, tendencje, koncepcje, instrumenty, red. Kuc B.R., Wyd. WSzZiM, Warszawa 2002.

Mockler R.J., The Management Control Process, Prentice-Hall, Englewood Cliffs, New York 1984. 
Organizacja i zarządzanie. Podstawy wiedzy menedżerskiej, red. Przybyła M., Wyd. AE we Wrocławiu, Wrocław 2001.

Schermerhorn J.R., Zarzadzanie. Kluczowe koncepcje, PWE, Warszawa 2008.

Schmid W., Leksykon menedżera, PSB, Kraków 2000.

Skorb-Gała A., Uwarunkowania organizacyjne procesu kontroli kierowniczej w przedsiębiorstwie, Rozprawa doktorska. Materiały niepublikowane, UE w Poznaniu, Poznań 2015.

\title{
MANAGEMENT CONTROL PROCESSES IN POLISH COMPANIES
}

\begin{abstract}
The aim of this paper is to contribute to the debate on the organizational control systems. The paper starts with presenting the concept and nature of the managerial control and defining of logic of management control process, that allow to present and discuss results of research on management control processes in Polish enterprises.
\end{abstract}

Keywords: management control process; organizational control systems; polish companies. 